\title{
PEMBANGKITAN WARNA ANGKA TOKEK DENGAN METODE LINIER CONGRUEN METHOD (LCM)
}

\author{
Haruno Sajati, Dwi Nugraheny, Antok Hermawan \\ Program Studi Teknik Informatika \\ Sekolah Tinggi Teknologi Adisutjipto Yogyakarta \\ informatika@stta.ac.id
}

\begin{abstract}
Color blindness is an abnormality in terms of seeing certain colors that occur as a result of demage to come cells (cone cells) in the retina of the eye, so that people with color blindness can be hard to catch a certaincolor spectrum. People suffering from color blindness would have difficulty distinguishing certain shades can not even see certain colors. Developed by Dr. Ishihara test Shinobu Ishihara in 1917, until now the Ishihara test methods still be one of the main option in almost all countries to identify someone who had color blindess. In the figure gecko color generation system with linear method congruen method $(\mathrm{lcm})$ described the components of software and hardwer that is required in the mamufacture of color generator application mumbers congruen gecko with a linear congruen method $(\mathrm{lcm})$. The determination of the initial value of the constant linear congruen method $(\mathrm{lm})$ into the determination of the color composition result generated randomly. System testing and completion of a questionnaire completed by Guttman and Likert scale. Diman on functional testing system results obtained with Guttman scale $100 \%$ yes that users can guess the number that appears on the color generation process. And the interface testing diselesaika with Likert scale with 85\% strongly agree result the system has a 94\% look attractive and easy to use system.
\end{abstract}

Keyword : color blindness, congruen linear method (lcm), figure gecko, Guttman scale, Likert scale

\section{Pendahuluan}

Buta warna merupakan ketidak normalan dalam hal melihat warna tertentu yang terjadi akibat kerusakan sel-sel kerucut (cone cell) pada retina mata, sehingga penderita buta warna akan sulit untuk menangkap suatu spektrum warna tertentu. Orang yang menderita buta warna akan kesulitan membedakan nuansa warna tertentu bahkan tidak bisa melihat warna tertentu. Buta warna bukan berarti buta terhadap seluruh warna, akan lebih tepat bila disebut gejala defisiensi penglihatan warna tertentu maupun kebutaan terhadap warna tertentu.

Untuk mengetahui apakah seseorang penyandang buta warna atau tidak, pada saat ini dokter mata melakukan test dengan menggunakan suatu buku test untuk melakukan test buta warna, buku tersebut dikenal dengan ishihara test yang terdiri dari plat atau lembaran yang didalamnya terdapat titik-titik dengan berbagai warna dan ukuran. Titik tersebut membuat lingkaran, warna titik itu dibuat sedemikian rupa sehingga orang buta warna tidak akan melihat perbedaan warna seperti yang dilihat orang normal. Alat test ishihara diakui dan digunakan secara international sebagai alat untuk penentu gangguan penglihatan atau kebutaan warna, namun dengan beredarnya buku tes buta warna dipasaran dimanfaatkan beberapa oknum penderita buta warna untuk mempelajari dan menghafalkan jenis plat buta warna dengan tujuan bisa lolos dalam suatu seleksi. 


\subsection{Tinjauan Pustaka}

Palupi dkk, 2015, Implementasi linier congruent method $(1 \mathrm{~cm})$ untuk Pengacakan Soal Ujian pada Aplikasi Belajar Hiragana, menjelaskan tentang Implementasi linier congruent method (lcm) yang digunakan pada proses pengacakan soal ujian pada aplikasi belajar hiragana, Dimana bilangan acak adalah suatu bilangan yang dihasilkan dari sebuah metode yang tidak dapat diprediksi hasil keluarannya. ). Dimana metode linear congruent method (lcm) dapat digunakan untuk meyelesaikan masalah yang mempunyai nilai acak seperti pengacakan soal Tryout SNMPTN. Pengacakan yang dihasilkan dengan linear congruent method $(\mathrm{lcm})$ menghasilkan nilai acak yang periodik, sehingga variabel yang diberikan harusselalu berubah-ubah. [5]

\subsection{Landasan Teori}

Tes buta warna Ishihara terdiri dari lembaran yang didalamnya terdapat titik-titik dengan berbagai warna dan ukuran. Titik-titik berwarna tersebut disusun sehingga membentuk lingkaran yang didalamnya terdapat titik-titik dengan pola membentuk angka maupun garis berbelok. Warna titik-titik itu dibuat sedemikian rupa sehingga orang buta warna tidak akan berhasil melihaat angka maupun garis yang ada. [4]

\subsubsection{Tes Buta Warna Metode Ishihara}

Tes buta warna adala uji prosedural yang digunakan untuk mengeahui kondisi kepekaan seseorang terhadap warna, apakah tergolong buta warna atau tidak. . Dimana metode ishihara memenfaatkan plat warna (colour plates), yaitu gambar-gambar berisikan pola warna melingkar yang membentuk angka tertentu. Bagi orang normal, angka dalam piringan warna akan cukup jelas terbaca. Namun bagi penderita buta warna, angka dalam piring warna tidak nampak jelas, terlihat kabur atau bahkan tidak terlihat sama sekali. [2]

\subsubsection{Angka Tokek}

Angka tokek merupakan alat atau instruksi atau alat penolong instruksi yang sering digunakan untuk test buta warna atau tes ishihara. [7]

\subsubsection{Model Warna RGB (Red Green Blue)}

Pemodelan $R G B$ diajaukan berdasarkan kenyataan bahwa besarnya presentasi dari keseluruhan spektrum warna yang visible (dapa dilihat manusia) dapat dibentuk atau direpresentasikan dengan pencampuran (mengkomposisikan) warna merah (red), hijau (green), dan biru (blue) dengan sekala pencahayaan dalam berbagai proporsi dan intensitas. [3]

\subsubsection{Skala Pengukuran}

Skala pengukuran merupakan kesepakatan yang digunakan sebagai acuan untuk menentukan panjang pendeknya interval yang ada dalam alat ukur.

Berbaggai skala sikap yang digunakan dalam penelitian, antara lain:

1) Skala Guttman

Skala pengukuran dengan tipeguttman akan mendapatkan jawaban yang tegas, yaitu yatidak dan lain-lainnya. Skala Guttman hanya ada 2 unterval jawaban yaitu setuju dan tidak setuju.

2) Skala Likert

Skala Likert digunakan untuk mengukur sikap, pendapat, dan persepsi seseorang atau sekelompok orang tentang fenomena sosial. Dimana di skala likert terdapat lima interval jawaban seperti sangat setuju, setuju, ragu, tidak setuju dan sangat tidak setuju. [6] 


\subsubsection{Rnd Function (Fungsi Acak)}

Rnd function adalah sebuah fungsi yang sangat bnyak digunakan dalam pemrograman dengan masalah peluang atau probability. [8]

\subsubsection{Linear Congruent Method (LCM)}

Linear Congruent Method (LCM) merupakan metode pembangkitan bilangan acak yang banyak digunakan dalam program komputer. Linear Congruent Method (LCM) memanfaatkan model linear untuk membangkitkan bilangan acak yang didefenisikan dengan :

$\mathrm{Xn}=\left(\left(\mathrm{a}^{*} X_{n-1}\right)+\mathrm{c}\right) \bmod \mathrm{m}$

Dimana :

$\mathrm{Xn}=$ Bilangan acak ke-n dari deretannya

$X_{n-1}=$ Bilangan acak sebelumnya

$\mathrm{a}=$ Faktor pengali

$\mathrm{c}=$ Increment (penambah)

$\mathrm{m}=$ Modulus (batas maksimum bilangan acak)

a, c, m adalah semua konstanta Linear Congruent Method (LCM) [1]

\subsection{Analisa dan Perancangan Sistem}

Pada sub bab ini dijelaskan komponen-komponen software dan hardware yang diperlukan dalam pembuatan aplikasi pembangkitan warna angka tokek dengan metode linie congruen method $(\mathrm{lcm})$.

\subsection{Analisa Sistem}

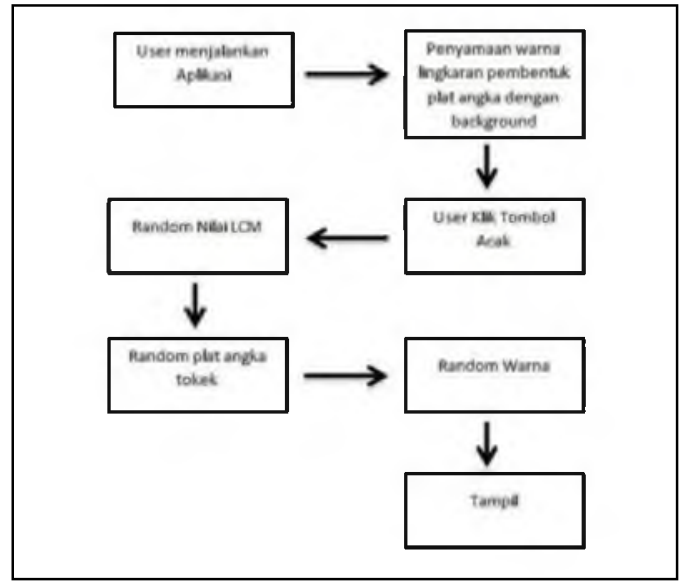

Gambar 1 Gambaran Sistem

Gambar 3.1 menunjukan konsep dari aplikasi pembangkitan warna angka tokek dengan metode linier congruen method (lcm) yang dibangun. Aplikasi ini merupakan aplikasi berbasis dekstop. 


\subsection{Perancangan Sistem}

\subsubsection{Perancangan Flowchart Sistem}

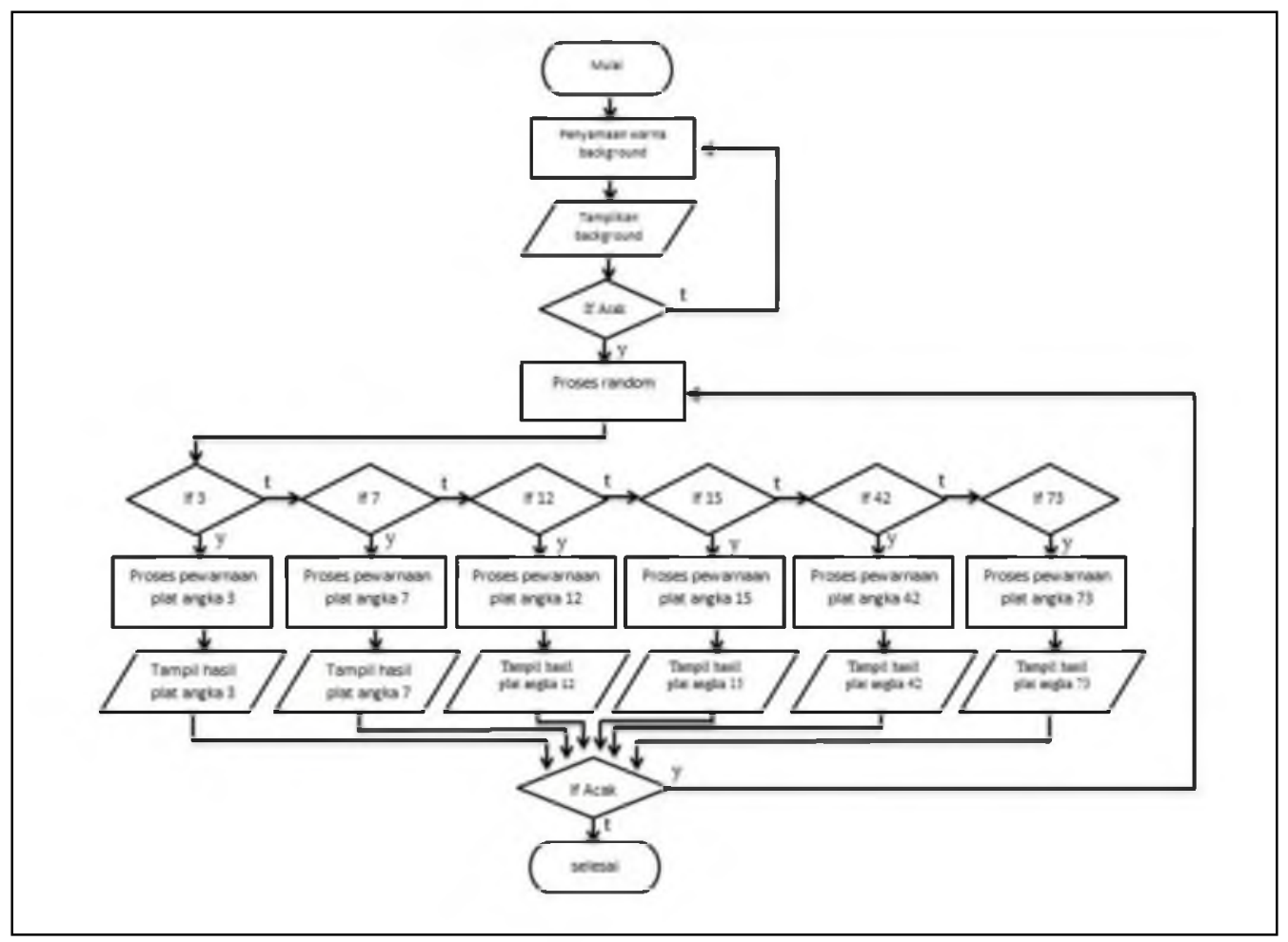

Gambar 2 Flowchart Sistem

Flowchart adalah langkah-langkah dan urut-urutan prosedur dari suatu program. Pada sistem pembangkitan warna angka tokek ini rangkaian langkah-langkah pembuatannya dapat dilihat pada flowchart gambar 2.

\subsubsection{Perancangan Sistem Diagram Konteks}

Diagram konteks merupakan diagram yangmenjelaskan proses perjalanan data dari satu atau beberapa source untuk mencapai suatu tujuan tertentu yang mana pada proses perjalanan data tersebut hanya terdapat satu proses saja yang digambarkan salam bentuk umum.

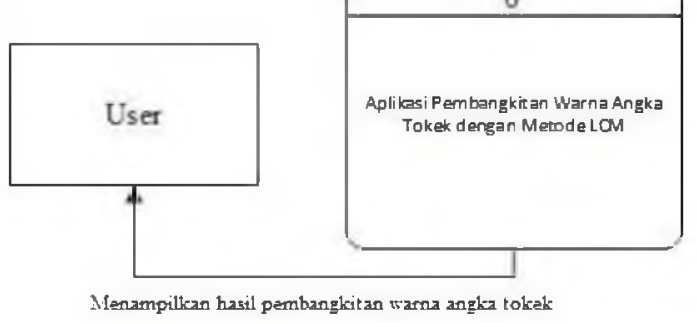

Gambar 3 Diagram Konteks Aplikasi

Gambar 3 merupakan diagram konteks aplikasi pembangkitan warna angka tokek dengan metode linier congruen method $(\mathrm{lcm})$. Pada Sistem ini hanya terdapat satu entitas yaitu user/pengguna. Dimana proses yang dapat dilakukan user terhadap sistem yaitu user dapat melalukan perintah acak dengan cara menekan tombol acak pada aplikasi pembangkitan warna angka tokek dengan metode linier congruen method $(\mathrm{lm})$ untuk menjalankan sistem. 


\subsubsection{Perancangan Sistem Diagram Alir Data Level 0}

DAD level 0 seperti yang ditampilkan pada gambar 4 merupakan pengembangan dari diagram konteks, dimana pada diagram ini menjelaskan bahwa terdapat tiga proses random.

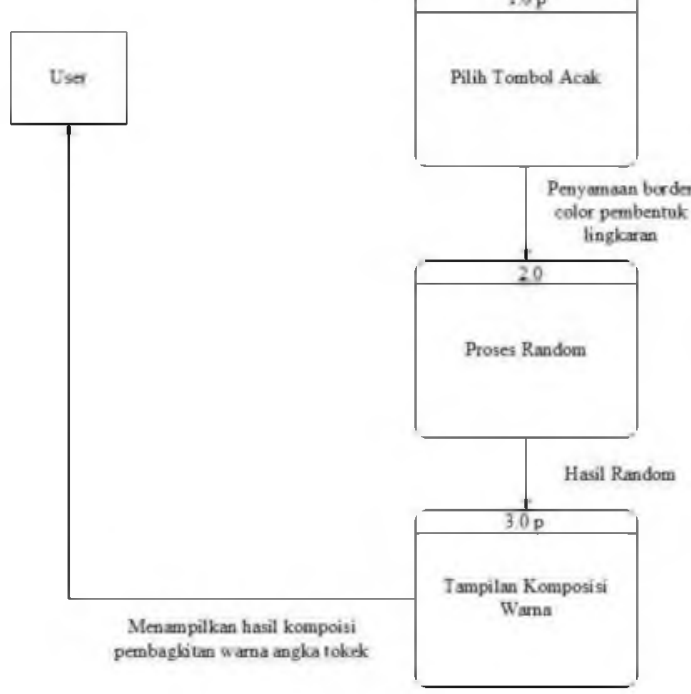

Gambar 4 Diagram Alir Data Level 0

Gambar 4 menunjukan diaram alir level 0 dari aplikasi pembangkitan warna angka tokek dengan metode linier congruen method $(\mathrm{lm})$. Pada diagram level 0 ini hanya terdapat 3 proses utama.

\subsubsection{Perancangan Sistem Diagram Alir Data Level 1}

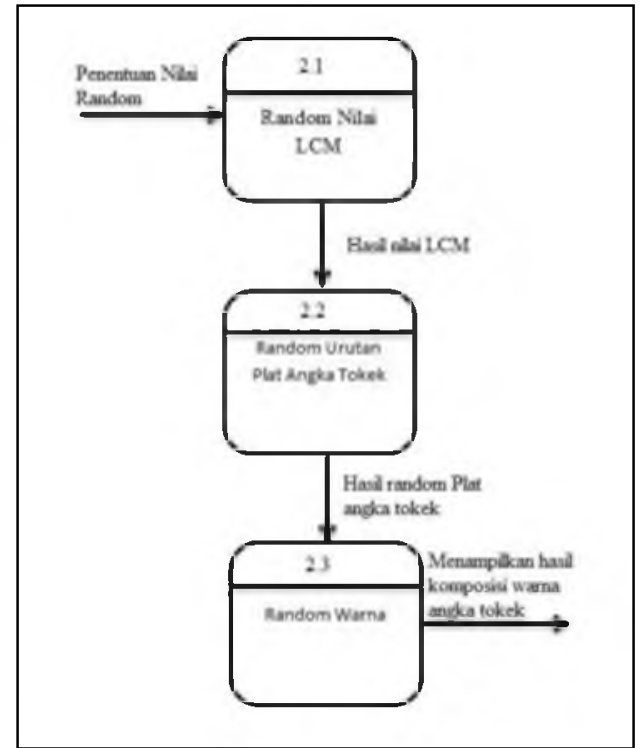

Gambar 5 Diagram Alir Data Level 1

Gambar 5 menunjukan keseluruhan proses random seperti random nilai linier congreun method $(\mathrm{cm})$, random urutan plat angka tokek, random warna rgb untuk menghasilkan komposisi warna angka tokek. 


\subsection{Implementasi Sistem}

Pada bagian implementasi sistem merupakan bagian yang mendiskripsikan suatu sistem agar sistem tersebut siap untuk dioperasikan. Bagian ini dilakukan setelah tahap analisisa dan perancangan sistem selesai. Tahap implementasi ini akan membahas mengenai desain halaman awal, utama dan plat angka tokek yang terdapat pada aplikasi pembangkitan warna angka tokek dengan metode linier congruen method $(\mathrm{lcm})$. Berdasarkan tahap implentasi tersebut diketahui apakah sistem yang dibuat benar-benar mencapai tujuan yang diinginkan.

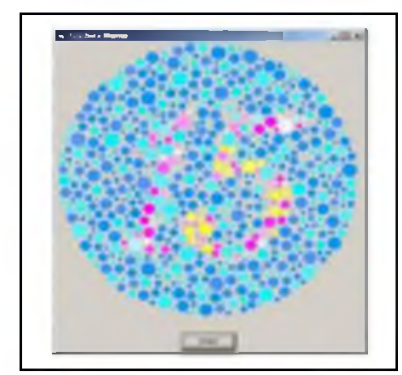

Gambar 6 Halaman Utama Aplikasi

Gambar 6 merupakan tampilan halaman utama dari aplikasi pembangkitan warna angka tokek dengan metode linier congruen method $(\mathrm{lcm})$. Dimana semua proses yang telah dibahas diawal semua akan diproses pada halaman utama ini.

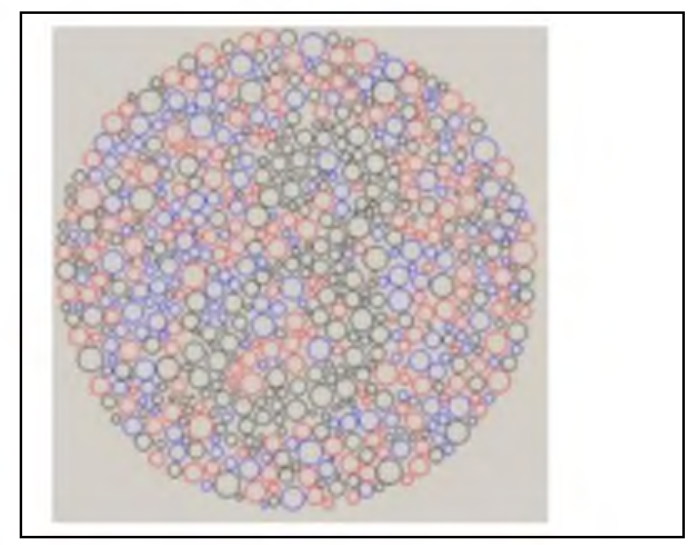

Gambar 7 Plat angkat tokek sebelum pembangkitan warna

Pada Gambar 7 Merupakan tampilan implementasi plat angka tokek tiga sebelum memasuki proses pembangkitan warna.

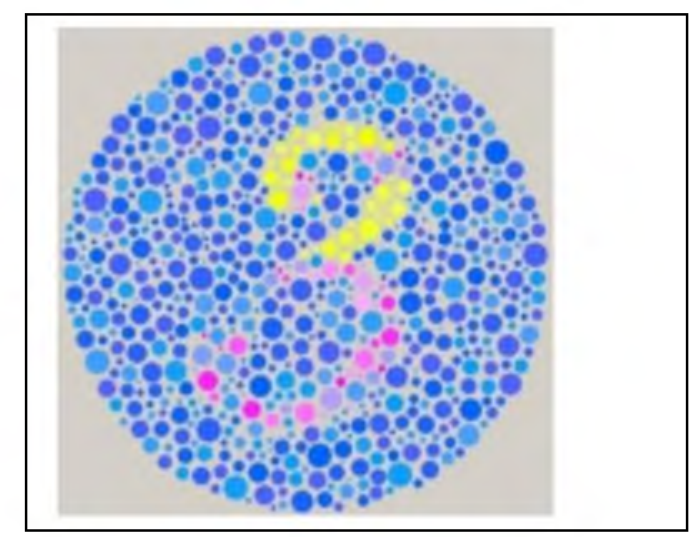

Gambar 8 Plat angka tiga tokek setelah proses pembangkitan warna ke 1

Pada Gambar 8 Merupakan implementasi tampilan plat angka tokek setelah proses pembangkitan warna pertama dimana terdapat empat warna pokok. 


\subsection{Pembahasan}

Dari uraian data pengujian sistem seperti diperoleh hasil pembangkitan warna angka tokek dengan metode linear congruent method $(\mathrm{lcm})$ dengan mengambil salah satu contoh angka hasil random $\mathrm{a}=7, \mathrm{c}=6, \mathrm{~m} 12, \mathrm{xr}=3, \mathrm{xn}=3$. Berikut data hasil perhitungan random pada proses pembangkitan warna dengan metode linear congruent method $(\mathrm{lcm})$ dapat dilihat pada tabel 1

Tabel 1 Data Hasil Pengujian Pembangkitan Warna

\begin{tabular}{|l|l|l|l|l|l|l|l|l|l|}
\hline \multirow{2}{*}{ No } & \multicolumn{4}{|l}{ Nilai Random } & \multicolumn{4}{l|}{ Warna } & \multicolumn{2}{l|}{$\begin{array}{l}\text { Hasil } \\
\text { Warna }\end{array}$} \\
\cline { 2 - 9 } & $\mathrm{a}$ & $\mathrm{c}$ & $\mathrm{m}$ & $\mathrm{Xr}$ & $\mathrm{Xn}$ & $\mathrm{R}$ & $\mathrm{G}$ & $\mathrm{B}$ & \\
\hline 1 & 7 & 6 & 12 & 3 & 3 & 26 & 270 & 240 & \\
\hline 2 & 7 & 6 & 12 & 3 & 3 & 26 & 150 & 150 & \\
\hline 3 & 7 & 6 & 12 & 3 & 3 & 23 & 150 & 150 & \\
\hline 4 & 7 & 6 & 12 & 3 & 3 & 73 & 240 & 270 & \\
\hline 5 & 7 & 6 & 12 & 3 & 3 & 765 & 52 & 480 & \\
\hline 6 & 7 & 6 & 12 & 3 & 3 & 360 & 210 & 23 & \\
\hline
\end{tabular}

Berdasarkan hasil data rgb pada tabel 1merupakan data akhir dari perulangan pembangkitan warna disetiap tingkatan pembentuk plat angka tokek. Dimana no 1,2, 3 merupakan tingkat penyusun plat angka tokek untuk bagian penyusun background, sedangkan untuk no 4, 5, dan 6 merupakan tingkat penyusun plat angka tokek bagian pembentuk angka. Dimana setiap penyusun plat angka tokek dapat menghasilkan warna $r g b$ yang berbeda-beda dengan nilai random yang sama, dengan ketentuan disetiap penyusun plat angka tokek penempatan nilai xn diacak diantara nilai $r g b$. Misal pada pada penyusun plat angka tokek ke 1 nilai xn ditempatkan pada warna $r g b g$ (green) dan pada penyusun plat angka tokek ke 2 nilai xn ditempatkan pada warna rgb b (blue) begitu seterusrnya untuk tingkat penyusun plat angka tokek yang lain. Dan untuk hasil warna rgb pada tabel 1 yang melebihi nilai 255 akan otomatis dikonversi oleh sistem menjadi nilai maksimal 255. Dari uraian data tabel 1 diperoleh hasil plat angka tokek yang di bangkitkan dapat dilihat pada gambar 9 .

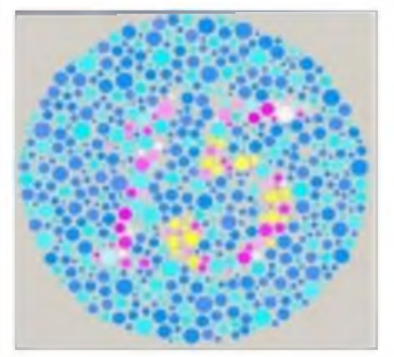

Gambar 9 Hasil Plat angka tokek dari data pembangkitan warna 


\subsection{Hasil Angket Pengujian Sistem}

1) Hasil Pengujian Fungsional Sistem dengan skala Guttman

Diperoleh data hasil penilaian fungsional sistem sebagai berikut :

Dimana terdapat pernyataan sejumlah lima dan memiliki jumlah penilaian dua dengan ketentuan nilai terendah enol dan nilai tertinggi satu dan dari tiga puluh koresponden menyatakan dapat menebak angka tokek yang muncul pada pembangkitan warna dan diperoleh hasil jumlah skor tertinggi dari penilaian fungsional sistem sebesar $100 \%$ bahwa hasil pembangkitan warna angka tokek yang dimunculkan sistem dapat ditebak seluruhnya oleh user.

2) Hasil Pengujian Antarmuka Sistem dengan Skala Likert

Maka penyelesaian akhir dari hasil sistem memiliki tampilan yang menarik sebagai berikut:

$=$ total skor $/ \mathrm{Y}$ x 100

$=128 / 150 \times 100$

$=85,3 \%=85 \%$ (Sangat Setuju)

Diperoleh hasil akhir Sangat Setuju bahwa sistem memiliki tampilan yang menarik

Dan Penyelesaian akhir dari hasil sistem mudah digunakan sebagai berikut :

$=$ total skor $/ \mathrm{Y} \times 100$

$=141 / 150 \times 100$

$=94 \%$ (Sangat Setuju)

Dan untuk pernyataan kedua juga diperoleh hasil akhir Sangat Setuju bahwa sistem memiliki tampilan yang menarik

\subsection{Kesimpulan}

Berdasarkan dari analisa terhadap Pembangkitan warna angka tokek dengan metode linier congruen method (lcm) dapat diambil kesimpulan yaitu :

1. Cara menampilkan plat angka tokek adalah dengan memanggil plat angka tokek yang dibuat sebelumnya secara random sebanyak enam plat angka tokek.

2. Penentuan konstanta linier congruen method (lcm) nilai faktor pengalih (a), penambah (c) dan batas maksimum bilangan acak (m) sangat menentukan baik tidaknya sempel acak yang diperoleh dalam arti memperoleh komposisi pembangkitan warna acak yang tidak terjadi pengulangan pada setiap plat angka tokek.

3. Metode linier congruen method $(\mathrm{lcm})$ bekerja sebagai pengacak nilai pada warna $\mathrm{rgb}$ sehingga warna yang dibangkitkan disetiap plat angka tokek berbeda dari angka tokek yang lain.

4. Hasil pengujian fungsional sistem dengan skala guttman diperoleh hasil $100 \%$ user dapat menebak angka yang muncul pada pembangkitan warna pertama sampai kelima

5. Hasil pengujian antarmuka sistem dengan skala likert diperoleh hasil $85 \%$ user sangat setuju sistem memiliki tampilan yang menarik, dan $94 \%$ suara sangat setuju bahwa sistem mudah digunakan.

\subsection{Saran}

Berdasarkan kesimpulan diatas, maka saran yang dapat diberikan untuk mengembangkan penelitian yang akan datang adalah :

1. Penambahan jumlah plat angka tokek yang lebih banyak 
2. Menentukan nilai warna $r g b$ yang tepat. Sehingga hasil dari pembangkitan warna dapat memiliki keteranganan gambar seperti pada tes Ishihara.

\section{DAFTAR PUSTAKA}

[1] Basuki Achmad, 2004, Membangkitkan Bilangan Acak Menggunakan Matlab, http://basuki.lecturer.pens.ac.id/lecture/BilAcak1.pdf

Diakses pada 10 November 2015, pukul 09.20 WIB

[2] D Hiru, 2015. Iridiologi Mendeteksi Penyakit hanya dengan Mengintip Mata,Jakarta: Gramadia Pustaka Utama.

[3] Fakultas matematika ITB, 2006.

http://www.fali.unsri.ac.id/userfiles/Penggunaan $\% 20 \mathrm{Warna} \% 20(\mathrm{~K})$.pdf

Diakses pada 7 November 2015,pukul 03.40 WIB

[4] Nur Rokhim Akhmad, 2012, Mengenal Tes Buta Warna, Yogyakarta: Rona Publising.

[5] Palupi.T.W, Djuniadi, 2015. Implementasi Linear Congruent Method (lcm) untuk Pengacakan Soal Ujian pada Aplikasi belajar Hiragama, Vol 2, No 2, Edukom, Semarang.

[6] Sugiono, 2013. Metode Penelitian Kuantitatif kualitatis R\&D, Bandung : Alfabeta.

[7] Woody Budi, 2014. http://www.frewaremini.com/2014/12/gambar-test-buta-warna-huruftokek-ishihara-colourblindess.html

Diakses pada 9 Februari 2016, pukul 8.50 WIB

[8] Rahmawati Indriana, 2013. http://ketikvisualbasic.blogspot.co.id/2013/05/fungsi-functionvisual-basic-6-bagian.html

Diakses pada 9 Februari 2016, pukul 10.25 WIpB 
